\title{
Revisiting the Evolution of International System: Reflections on the Role of Religion
}

\author{
Sarwar J. Minar*
}

\begin{abstract}
Religion has been significant in human life since the day of human creation and since then played important role throughout various phrases of the world history. The paper investigates the role of religion in the development of International System. In tracing out the role of religion, the paper uses a qualitative research method. Though an interpretive approach, the paper explores the role of religion from the very beginning moment of creation of earth and human being, throughout various historical development phrases. The paper finds that religion has historically played a significant role in human life, in the organization of the social entities, and therefore in the relations among them. The paper finds immense influence of religion in prehistoric societies, in the pre-Westphalian system, in the city states and empires. However, in the Westphalian era religion was left aside and secularism took the place but was not excluded entirely. In the present era religion has again emerged as an influential force in the world affairs. Presenting an evaluation of religion's role in the $21^{\text {st }}$ century international system, the paper concludes attempting to integrate religion into the theories of International Relations.
\end{abstract}

\section{INTRODUCTION}

Religion has been an inextricable part of human life which has been significantly influencing almost all aspects of human life throughout human history. Religion significantly influences human life, their thinking, the way they act and the relations they maintain. In the same way religious power also influences group conduct, group to group relations, state policies, alliance selection, and state to state relations. Thus, religion has a significant influence in the functioning of the international system. However, as the most basic unit of 'interaction' was individual human being who was immensely influenced by religious thinking. As acted according to religious tenants, therefore, the system that has developed over centuries and has taken the vastness to be 'international' has been being fundamentally influenced by religion from below. Religion's role throughout history has been both dramatic and profound - it has caused war and peace. It has both assisted and crushed rebellions. Religion has major influence because of the direct effect of religious belief amongst individuals. Religion has been important in all about great powers throughout history and played important roles in decisions of war, peace, and everything in between. Religious scriptures and religious teachings tell billions of people what to do, how to act and so on, so, it is of little surprise that when individuals become important in politics, their religious opinions matter in shaping their decisions and actions. Thus, International relations has also been shaped by the religious institutions which have been powerful as of religious beliefs. Institutions such as the Papacy and the Church of England have wielded great power throughout the history.

This paper examines the central research question; what role did religion play in the development of International System? This paper is divided into five main parts. First part attempts to map a theoretical framework of religion. Second part takes the task of defining religion and international system. The third part investigates the role of religion in the pre-historic, pre-Westphalian system and in the Westphalian system. The fourth part deals with contemporary resurgent of religion in the world affairs. Lastly, the fifth part investigates how religion can be integrated with the theories of International Relations.

\section{METHODOLOGY (RESEARCH DESIGN)}

In order to investigate the role of religion in the international system, the article uses a qualitative research method. Due to the very nature of the topic and investigation, only secondary data is used which are available in the form of academic journals, books, book reviews, documents, magazines, working papers, study reports and newspaper articles. The texts of Holy Quran and the Holy Bible are reviewed. Additionally, data from relevant websites and e-documents are used.

\footnotetext{
* Sarwar J. Minar, Senior Officer, International Programs and Relations, Independent University, Bangladesh (IUB) 
Rationale of the Research: This research contributes to reexamining the systemic development of international system and contributes to understand the role of religious dimension in it. The article fills the knowledge gap of religions' contribution to the evolution and development of international system today. The findings will satisfy emerging new demand of studying and integrating religion in the study of international relations as there have been repeated claims to reexamine the role of religion in the $21^{\text {st }}$ century to better understand world affairs and International Relations. Friedrich Kratochwil commented, 'The intersection of religion and international relations has become a major focus for the analysis of contemporary International Relations'. ${ }^{1}$ Similarly Jonathan Fox has asserted that 'no understanding of International Relations can be complete without bringing religion into the discipline'. ${ }^{2}$ Therefore, this research paper will contribute to the better understanding the development and functioning of international system today especially the role of religion in it.

\section{A THEORETICAL FRAMEWORK}

Theories of Religion introduce classic attempts to explain religion scientifically. Theories of religion can be divided into two categories. Firstly, substantive theories that focuses of what religion is and secondly, functional or reductionist theories that focus on what religion does. Substantive theories include theories given by E.B. Tylor and James Frazer, Rudolf Otto, Mircea Eliade etc. and functional theories include theories given by Karl Marx, Sigmund Fraud, Emile Durkheim etc.

Tylor and Frazer focused on the explanatory value of religion for its adherents. Theologian Rudolf Otto focused on the importance of religious experience, more specifically experiences that are both fascinating and terrifying. Mircea Eliade focused on the longing for otherworldly perfection, the quest for meaning, and the search for patterns in mythology in various religions. ${ }^{3}$

Influential functional theories have been proposed by a number of scholars. Karl Marx focused on the economic background, Sigmund Freud focused on neurosis as a psychological origin of religious beliefs and Émile Durkheim focused on the social function of religions. Marx wrote religion as "opium of general mass" ${ }^{4}$ he further said it is because "man makes religion, religion doesn't make man" and is used to keep people alienate from consciousness of exploitation. ${ }^{6}$

'Evolutionary Theory' argues that the system developed through an evolutionary process in the line with the evolution of human beings. That is the international system of today is the result of evolution. The 'Sword Theory' argues that the religion spread through the use of power and domination over many groups, tribes and nations and ultimately shaped the present international system. The "Persuasion Theory" argues that the spread of religion was undertaken through preaching of Pirs, Sufis, Fakirs and so on and thus the religion based communities came to communicate with each other. Thus, religion played a key role in the gradual development of various systems and ultimately the international system. ${ }^{7}$

\section{DEFINING RELIGION AND (INTERNATIONAL) SYSTEM}

Religion. The meaning of religion used in this article is the beliefs, rituals or discourse that influence human life significantly, almost all aspects of life and guides human and other entities' actions. A discourse might construct religion through specifying the range of objects that are included or excluded, for example, one might include Buddhism and Zoroastrianism, while excluding witchcraft and ballroom dancing, on the other hand, another sense is that the internal classification of religion, for instance, between inclusive and exclusive forms of religion, moderate and extremist religion. ${ }^{8}$ Darwin's theory of evolution can also be applied, the religion to be developed through an evolutionary process of human being. Frazer developed an evolutionary theory, tracing religion to develop from magic. Taylor defined religion as "religion is belief in spiritual beings," His animism is also sort of evolutionism.

\footnotetext{
${ }^{1}$ Friedrich Kratochwil, "Religion and (Inter-) National Politics: On the Heuristics of Identities, Structures, and Agents", Alternatives vol. 30 (2005), p. 113.

${ }^{2}$ Fox and Sandler, Bringing Religion into International Relations, Available at http://books.google.com.bd/books/about/Bringing_religion_into_international_rel.html?id=6g85Cs16YhsC\&redi r_esc=y, Accessed on November 25, 2011.

${ }^{3}$ Daniel L. Pals, Seven Theories of Religion, (Oxford: Oxford University Press, 1996), p.1-14.

${ }^{4}$ Ibid., p.141.

${ }^{5}$ Ibid., p. 140.

${ }^{6}$ Ibid.

${ }^{7}$ Aksadul Alam, Islamisation in Bengal: A Review of Theories, A Paper Presented at an International Conference, New Delhi, January 27, 2005.

${ }^{8}$ Edmund Frettinghum (PhD Dissertation), "Security and Construction of Religion in International Politics", p.7., Department of International Politics, Aberystwyth University, 2009.

${ }^{9}$ Daniel L. Pals, Op.cit., p.24.

DOI: $10.9790 / 0837-2307106270$

www.iosrjournals.org 63 | Page
} 
System. System refers to an integrated whole consisting of its intra and inter related parts which are continuously interacting with each other and ultimately gives meaning to its elements and works for an ultimate purpose. There have been various tires of systems for instance local, national, regional and global. Human to human interaction is the basis of all such systems. However, Joshua S. Goldstein defined, "International system as a set of relations among world's states, structured by rules and patters of interaction." ${ }^{10}$ Therefore, 'system' refers to a structural arrangement of its units connected to each other as networked and it is the integrating whole of its units that consist the system and the system that is international in nature is known as 'international system'.

\section{THE EVOLUTION OF INTERNATIONAL SYSTEM: SEEKING THE MISSING LINKS}

Human beings have evolved through long and complex processes. First system was limited within human to human interaction. It gradually expanded to a local level, then to a regional level and finally to international level. However, religion contributed greatly to the development of the system. Additionally, religion helps to order the system; change in religion and its influence can disorder and reorder the international system. Snyder argues that religion can alter the basic patterns of international relations: who the actors are, what they want, what capacities they have to attract support, and what rules they follow. ${ }^{11}$ Therefore, the paper explains the role of religion in the development of system and international system in four stages: pre-historic stage, pre-Westphalian stage, Westphalian stage and post Westphalian stage systems. Each of them is described below:

\subsection{Pre-Historic Period}

By pre-historic period this paper means the time period from the creation of man. That is the time before recorded history as there is hardly any evidence to make reference of this period. Religious scriptures give explanation of that period. From Quranic explanation, Allah created all the living creatures of the world. ${ }^{12} \mathrm{He}$ created men from dry clay ${ }^{13}$ and sent Adam (first human) to the earth as his representative in the world. ${ }^{14}$ Allah created the world and the galaxy in two days and arranged all other facilities in another four days. He is all powerful ${ }^{15}$ and he controls everything. ${ }^{16}$ From Biblical explanation, God created Adam (first man) from dust and then created first women as his wife. ${ }^{17}$ God created light and separated it from darkness ${ }^{18}$ and gathered water in one place and made dry land to appear ${ }^{19}$ and then created man in his own image. ${ }^{20}$

Man is the very fundamental unit of systemic interaction and the very primary system that evolved was based on human to human interaction. This can also be said as the 'microcosm' of bigger system. During that time each and every aspect of life used to be maintained by religious dictum. Therefore, religion played a decisive role in the pre-historic system.

\subsection{Pre-Westphalia System: Religion Based System}

Since the recorded history of human evolution till Westphalian system is considered as pre-Westphalian system. Although Westphalian system is purely a western system as that later gained international acceptance this paper takes Westphalian system as standard system. However, systems of other parts of the world are taken into consideration. The paper divides the pre-Westphalian system into a number of sub-parts. These are Sumerian city state system (3000 BC), Greek city state system (500 BC), Empire systems (Macedonian Empire - 800-146 BC, Roman Empire - 31BC-476 AD, Western Byzantium Roman Empire, Eastern Arabic Empire, Ottoman Empire 1299-1453 AD), and Khilafat system.

Sumerian City-State System. This system existed around 3000 B.C. and this was totally agriculture oriented city state system. They were the first people whose history has been reconstructed. They lived in the valleys adjacent to Tigris and Euphrates rivers. City states were independent but there was no central authority.

${ }^{10}$ Joshua S. Goldstein, International Relations (Singapore: Pearson Education, 2004), Fifth Edition., p.17.

${ }^{11}$ G. John Ikenberry, "Religion and International Relations Theory", September/October 2011, Available at http://www.foreignaffairs.com/articles/68139/religion-and-international-relations-theory-religion-culture-and\#, Accessed on November 16, 2011.

12 Holy Al Quran, Surah Nur: 45,

${ }^{13}$ Holy Al Quran, Surah Hizr: 26,27

${ }^{14}$ Holy Al Quran, Surah Al Bakara: 30

${ }^{15}$ Holy Al Quran, Surah Ha-Mim Sejdah: 9-11.

${ }^{16}$ Holy Al Quran, Surah Al Yonus: 3

${ }^{17}$ Holy Bible Genesis 2:4-2:25

${ }^{18}$ Holy Bible Genesis 1:3

${ }^{19}$ Holy Bible Genesis 1:9-10

${ }^{20}$ Holy Bible Genesis 1:27, Available at http://bible.cc/genesis/1-27.htm, Accessed on 23 November 2011.

DOI: $10.9790 / 0837-2307106270 \quad$ www.iosrjournals.org $\quad 64 \mid$ Page


Conflicts among them were settled through conflict or bargaining of power. 'Umma' and 'Lagash' were two prominent independent city states. ${ }^{21}$ During those days religious practices were heart of peoples' life. Therefore, their pattern of interaction was greatly influenced by religion.

A number of civilizations developed subsequently which came to known as 'New World'. Such civilizations include Egyptians, Hittites, Indians, Chinese, Hebrews, Assyrians, Maya and so on. ${ }^{22}$

Greek City-State System. Greek city states existed from 500 B.C. to 100 B.C., also known as Hellas. Athens was the largest and most famous. Sparta and Corinth were also well known city states of that time. Together they formed a city state system. City states were smaller in terms of population and territory. The city state system was based on shared language and religion, religion influenced the system greatly. ${ }^{23}$

Empire Systems. Gradually various city states were integrated into larger empires. Empire system dominated history of states for centuries in Rome, other empires in China and in the East. Empires sustained through accumulation and concentration of coercive means. They frequently crossed long distances trading routes and engaged in trades. There were polities within each empire. A tribute system was there for supporting the emperor, his administrative apparatus and military. Religion was a binding force for the people of that time and this influenced people's life at that time. ${ }^{24}$

The Romans developed a huge empire in course of conquering, occupying and ruling most of the Europe, large part of Middle East and North Africa. Romans had to deal with numerous sub-ordinate political communities. Religion worked as a strong force at that time. As gradually Romans could not control rebellion of the small polities, Roman Empire ultimately collapsed. Two successor empires emerged: the 'Western Empire' in catholic empire based on Christendom and the other one was the 'Eastern Empire' near east of byzantine centered in today's Istanbul where gradually Ottoman Empire emerged later on..$^{25}$

In China, confucianism was a moral code that served as a basis for life in Imperial China, even before second century BCE. The founder of Taoism established a number of gods that corresponded to the range of traditions, and Daoist priests were permitted to add gods. Confucianism in East Asia survived the region's modernization and is now an important tool for bolstering state authority and regional identity there. ${ }^{26}$

Khilafat and State. The Arabic word Khalifa (Caliph) means successor, Khilafat refers to the Islamic institution of spiritual successorship; caliphate implies a politico-religious Muslim state governed by Caliph which can be interpreted as the basis of an Islamic polity run by rules of the Quran and Sunnah. According to Hazrat Mirza Tahir Ahmad the role played by a Khalifa was both spiritual and secular. Khalifa being the spiritual head of a confederation of states is that the Khalifa may relegate most or all his secular authority to the elected representatives of the members of the confederation. Thus, the concept of Khilafat transcended national sovereignty and ethnic divide and formed a truly universal supra-national entity. He was bound by the ordinances of divine law. He used to decide questions of policy after consultation with the chosen representatives of the people. The concept of Khilafat was thus imbued with both secular and religious characteristics. ${ }^{27}$ When the Prophet Muhammed died, Abu Bakr succeeded to his spiritual, political, and administrative functions as successor of the messenger of God. Then Umar, Uthman, and Ali became successors. After the end of the rightly-guided Khilafat, the title of Khalifa was borne by the fourteen Umayyad kings of Damascus (661-750 A.D.) and subsequently by the thirty-eight Abbasid monarchs of Baghdad (750-1258). After the fall of the Umayyad dynasty, the title was then assumed by the Spanish branch of the family who ruled in Spain at Córdoba (755-1031 A.D.) and by the rulers of Egypt (909-1171 A.D.). Thus, there existed multiple contemporaneous caliphs from the 7th to 12 th centuries. The last titular Abbasid Caliph of Cairo was captured in 1517 by the Ottoman Sultan, Selim I.

${ }^{21}$ Theodore Coulombis and James Wolfe, Introduction to International Relations: Power and Justice. (PrenticeHall: Englewood Cliffs, N.J, 1978), p.17.

${ }^{22}$ Ibid.

${ }^{23}$ Robert Jackson and George Sorenson, Introduction to International Relations: Theories and Approaches

(Oxford: Oxford University Press, 2003), Chapter1, p.11.

${ }^{24}$ David Held, "The Development of Modern State" in Stuart Hall and Bram Gieben, eds. Formations of

Modernity (Cambridge: Polity Press, 1995), Chapter 2, p.79.

${ }^{25}$ Theodore Coulombis and James Wolfe, Op.cit., p.11

26 "Religion and Modern State", Available at http://www.whyreligion.com/titles/r63.htm, Accessed on 29

November 2011.

${ }^{27}$ Rafi Ahmad, "The Islamic Khilafat - Its Rise, Fall, and Re-emergence", Available at

http://www.alislam.org/egazette/updates/the-islamic-khilafat-its-rise-fall-and-re-emergence/, Accessed on

November 25, 2011.

DOI: $10.9790 / 0837-2307106270$

www.iosrjournals.org

$65 \mid$ Page 
The Ottoman sultans then claimed the title of Khalifa and brandished it for four centuries until it was abolished in 1924 by the Mustafa Kamal Ataturk, the founder of Turkish Republic. ${ }^{28}$

Political leaders lost their religious enthusiasm and ceased to contest religion as a political affair. There is also little record of any religious matter being adjudicated through imperial institutions. Finally, for over a century and a half before Westphalia, unlike after Augsburg, neither princes nor the emperor intervened to contest religion within another prince's territory. Even though later European treaties compromised sovereignty on behalf of religious minorities, never again intervened for religion play anywhere near the role that it did between 1517 and 1648. The Reformation touched off civil wars within the Habsburg Empire and within other territorial jurisdictions, which spread through transnational networks linking like-minded actors with common strategic concerns in different territorial entities. ${ }^{29}$

\subsection{Westphalia State System: Is Religion Really Left out in Modern State System?}

Westphalian Settlement with the codification of modern international relations established a new system, the Westphalian system. The formulations of sovereignty became the center piece of Westphalian system which bought revolution to the overall system. Jean Bodin defined sovereignty as 'absolute and perpetual power vested in a commonwealth'. Although all Bodin's sovereign powers were without limit they were ultimately limited by natural or divine law. "... all the princes on earth are subject to the laws of God and of nature". ${ }^{30}$

The treaty of Westphalia embraced the notion of sovereignty; all small states of the central Europe became sovereign. Monarchs were given the authority to choose the version of Christianity Catholicism or Protestantism on behalf of the people. The sovereign enjoyed exclusive right within a given territory. Leaders sought to establish own military power rather than relying on mercenaries and this gave more power to the hand of the central ruler. Thus, a secular base was firmly established. ${ }^{31}$

Ruggie's 'heteronymy' pointed the lines of transnational religious authority directly shape the allegiances and goals of armed actors, but religion could also shape behavior in pure anarchies. As different religious cultures might develop different strategic cultures that shape choices within this band of ambiguity. Indeed, territorial leaders prospered when they could harness popular religious enthusiasms to their purposes, and conversely religious groups survived only if they received backing from a territorial unit. ${ }^{32}$

Despite the separation of state and church associated with the development of the secular state since the seventeenth century, at least in Europe and its outposts, one could reasonably argue that religion and faith have never been entirely absent from the stage of international relations and world politics. They have been vehicles for conflict and the pursuit of power, on the one hand, and driving forces in humanitarianism and social justice on the other. Religion, especially Christianity, was central to the imperial mission, the 'mission civil trice' which sought not only to acquire territory and resources for economic and political gain but also to bring Christian civilization to 'barbarians' at the same time as it sought to subjugate them. Christian missionaries established to spread as well as to convert people into Christian. ${ }^{33}$ Therefore, although with the rise of secularism religion was not totally set apart, religion was totally left rather embedded into their social life and various practices.

\section{TOWARDS A POST-WESTPHALIAN SYSTEM: RESURGENCE OF RELIGION?}

Globalization has brought revolutionary changes in world affairs. With globalization and revolution in communication and transport system the world is now called to be a 'global village'. With economic globalization state's economic management monopoly has been curbed, with the rise of regional and international institutions state's political authority has also weakened, and with the rise and rapid spread of private military organizations as well as their demand from state actors has weakened military mechanism of state. Globalization has made people to think them to be global citizen rather than of a single state. Reversely, the rise of International terrorism has disrupted international peace and security. Taking advantages of the globalization terrorists are planning and undertaking attacks worldwide. The United States' main land has been attacked by the terrorists for the first time in history.

\footnotetext{
${ }^{28}$ Ibid.

${ }^{29}$ Ibid., p. 213.

${ }^{30}$ Karen Mingst, “The Historical Context of Contemporary International Relations”, Essentials of International Relations (New York: Norton, 1998), Chapter 2, p.27.

31 Ibid., p. 28.

${ }^{32}$ Lorraine Elliott, Mark Beeson, Shahram Akbarzadeh, Greg Fealy and Stuart Harris, "Religion, Faith and global politics", Published by Department of International Relations (RSPAS), The Australian National University, July 2006.

${ }^{33}$ Ibid.

DOI: $10.9790 / 0837-2307106270$

www.iosrjournals.org 
Thus, religion has also been globalized in the globalized world. The September $11^{\text {th }}$ terrorist attacks were carried out by religious fanatics partially for religious reasons. Religion is now widely claimed to be back at the cross board of International Politics. Elizabeth Shakman Hurd observes, 'It is now unsustainable to claim that religion plays no significant role in international relations; it has become a critical consideration in international security, global politics, and U.S. foreign policy'. ${ }^{34}$

\section{THE IMPACT OF RELIGION IN CONTEMPORARY INTERNATIONAL SYSTEM}

Religion strikes back in the $21^{\text {st }}$ century. Present 'nation state system' and therefore the 'international system' has been troubled by terrorism and radicalism. So, a question comes up, does religion bring only negative consequences for the world? The answer should be "No". As the central goal of religion is to establish and spread peace, therefore, the underlying motivations of various religious groups' deadly attacks and terrorist activities should not be left alone on religious reasons. The influence of religious communities on politics and policies - real as it is - must not be overestimated eluding underlying other causes. The sources of conflicts and the course of conflict processes are highly complex. Religious factors often play only a subordinated role as a source of conflicts but underlying causes lie in occupation, exploitation and deprivation etc. Eric O. Hanson has proposed a new paradigm of world politics which is focused on religion's role in world politics. He proposed the new paradigm of politics and religion within the technology driven EMC (Economic, Military and Communication system) system. ${ }^{35} \mathrm{He}$ argued religion has played a major role in local politics by constituting a civilization's basic unit. Religion of the villages is the life of the village, he added. ${ }^{36}$ However, conscious use of religion can play a decisive role in the construction of world peace in the future.

\section{VIII.A THEORETICAL ANALYSIS: INTEGRATING RELIGION INTO THE THEORIES OF INTERNATIONAL RELATIONS}

In the post 9/11 era religion has emerged as a central topic on world politics. Such development demands deeper attention towards studying religion. However, theories of International relations hardly integrate religion. Jack Snyder pointed "One reason for the neglect of integrating religion into international affairs is that mainstream international relations scholars find it difficult to integrate religious subject matter into their normal conceptual frameworks". 37

The three dominant paradigms of International relations are Realism, Liberalism and Constructivism. Neither of Kenneth N. Waltz's neo-realism, Michael Doyle and Robert Keohane's Liberalism or Alexander Wendt's Constructivism integrates religion. However, Jack Snyder's book "Religion and International Relations Theory" contributes to the integration of religion in the theories of International Relations. ${ }^{38}$

Religion and Realism. Realism is a state-centric analysis that focuses mainly on power, fear and anarchy. Realism gives important explanations for conflict and war. ${ }^{39}$ In international relations political realism refers to a tradition of analysis that stresses the imperatives states face to pursue a power politics of national interest. ${ }^{40}$ According to classical realism, a variant of realism, states behavior is driven by leaders' flawed human nature or mandated by an anarchic international system. ${ }^{41}$ The role of religion in shaping leaders' psyche needs to integrate into the studies. Another variant of realism is neo-realism, as Kenneth N. Waltz described neo-realism in terms of 'the ordering principle', 'differentiation of unit' and 'distribution of power'. Religion can be integrated in all of the three aspects of neo-realism. ${ }^{42}$

First, 'The Ordering Principle of the International System'. This basically constitute how the units are arranged relative to each other in the hierarchy, a system of rule-governed authority relations between units, and

\footnotetext{
${ }^{34}$ Elizabeth Shakman Hurd, "The Politics of Secularism in International Relations", (Princeton: Princeton University Press, 2008), p. 134.

${ }^{35}$ Eric O. Hansen, Religion and Politics in the International System Today (Cambridge: Cambridge University Press, 2006), p.17-46.

36 Ibid., p.48.

37 Jack Snyder, Religion and International Relations Theory, (New York: Columbia university press: 2011), p.1., Available at

http://books.google.com.bd/books?id=O51O6_cMgAQC\&printsec=frontcover\&source=gbs_ge_summary_r\&ca $\mathrm{d}=0 \# \mathrm{v}=$ onepage \&q\&f=false, Accessed on November 28, 2011.

${ }^{38}$ Ibid., p.2.

${ }^{39}$ Paul D. Williams, “Constructivism”, In Security Studies: An Introduction, (New York: Rutledge, 2008), p.15.

${ }^{40}$ Jack Donnelly, "Realism", Theories of International Relations eds by Scott Burchill, Andrew Link later, Richard Davetak, (New York: Palgrave Macmillan, 2005), p.29.

${ }^{41}$ Paul D. Williams, Op.cit., p.16.

42 Jack Snyder, Op.cit., p.2.

DOI: $10.9790 / 0837-2307106270$

www.iosrjournals.org $67 \mid$ Page
} 
anarchy, a system in which units seeking to survive due to lack any authority above them to set and enforce rules or guarantee agreements between them. Politics within states is normally hierarchical, whereas politics between states is normally anarchical. Anarchy tends to be self-perpetuating through the mechanism of unit self-help and the balance of power. Realists admit that anarchy could give way to hierarchy-for example, if a single unit, such as the ancient state of Chin, should conquer the rest of the relevant actors in an interacting system. However, religion may play a decisive role in determining the ordering principle of the system in the first place, as well as significantly influencing the behavior of units in the system once it is constituted. States are the central unit of international politics. From a Weberian standpoint, states are organizations that monopolize legitimate violence within a territory, and religion is often the trump card in claims to social legitimacy. Michael Mann and Rodney Stark showed how religions facilitated the collective action and legitimacy that such civilization-sized, multilinguistic empires needed to survive and prosper. Size and shape of the empire could depend heavily on which social networks were amenable to penetration by the empire's religious ideology. The rise of a new religion, such as Islam, could directly give rise to a new empire, and a schism within religion, such as the protestant reformation, could break down imperial hierarchy and return it to anarchy. Religion helps to order the system. Moreover, change in religion can disorder and reorder the international system. Religion not only plays a central role in constituting the basic ordering principle of the system, but it can also shape specific behavioral choices and patterns within an ordered system. Additionally, a different religious culture might develop and like different strategic cultures that shape choices can shape choices profoundly. ${ }^{43}$

Second, 'Differentiation of Units'. In hierarchies, the units do participate in a functionally differentiated division of labor; in anarchies, they do not, because a substantial degree of self-sufficiency of the territorial state improves its chance of survival. Functional differentiation means interdependence and therefore vulnerability, which states in anarchy seek to minimize. Before modernization, political authority was not as sharply differentiated from religious authority. Kings ruled by divine right and wielded religious authority over their subjects, and Popes and abbots did have their own military "divisions". Anthony Marx has argued that the wars of religion following the Protestant Reformation were simply a transitional stage on the way to the wars of secular nationalism that began with the French Revolution and continue down to the present. ${ }^{44}$

Third, 'Distribution of Power' refers to the distribution of power across its units, in particular the number of great powers. Social power has to be recognized including material power which rests on some combination of coercion, legitimate authority, persuasion, and mobilization of support. Religion might be central to generating power by almost any of these means. Religious enthusiasm has been an effective motivator of military rebellion. Religion may delimit the scope of an actor's power or influence which tools can be deployed in which social settings. According to Haynes, "the capability of an entity, usually but not necessarily a state, to influence what others do through attraction and persuasion". ${ }^{45}$ Therefore, religion has an influence on distribution of power. $^{46}$

Offensive realism, another variant of realism, argues international system is anarchic, states are main actors, every great power has some offensive capabilities, states can never be sure of other's intention therefore great powers tend to establish hegemony in the region to ensure its security. Religion can play a decisive role in establishing hegemony in a particular region whole opposing of religion can make that much harder. ${ }^{47}$

Religion and Liberalism. Michael Doyle's liberalism arose in the wake of the protestant reformation and the protestant ethic of the capitalist middle class. Much of liberal enlightenment thought was grounded in a Christian form of secularism. In international affairs, protestant dissenters operating in the conducive environment of protestant-dominated liberal democratic hegemonic states were in the vanguard of the peace and free trade movements and the movement to suppress slavery. Democratic peace should mainly be understood in terms of its liberalism's normative roots in religion rather than in terms of mechanical procedures of electoral accountability, checks and balances. Religion proposes an intellectually coherent interpretation of natural, supernatural, and social reality, and creates a specialized institution to carry out religious ritual and to transmit and develop religious doctrine. Religious organizations were thus forerunners of modern bureaucratic secular organizations. ${ }^{48}$

\footnotetext{
${ }^{43}$ Jack Snyder, Op.cit., p.8-10.

${ }^{44}$ Jack Snyder, Op.cit., p.10-12.

45 İştar Gözaydın, "Religion as Soft Power in the International Relations of Turkey”, Available at

http://www.google.com/url?sa=t\&rct=j\&q=religion\%20as\%20soft $\% 20$ power\%20in\%20the $\% 20$ international $\% 2$ Orelations $\% 20 \mathrm{of} \% 20$ turkey $\% 20 \&$ source=web\&cd=1\&ved=0CB0QFjAA\&url=http $\% 3 \mathrm{~A} \% 2 \mathrm{~F} \% 2 \mathrm{Fwww}$.psa.ac.u k\%2Fjournals\%2Fpdf\%2F5\%2F2010\%2F1365_1228.pdf\&ei=A3PpTtu2F421hAea-

YTZCg\&usg=AFQjCNEkIUFwOiPPROjzHmAEEaQyYQ5x5g\&cad=rja, Accessed on November 29, 2011.

${ }^{46}$ Jack Snyder, Op.cit., p. 12.

${ }^{47}$ Jack Snyder, Op.cit., p.13.

48 Jack Snyder, Op.cit., p.13-15.

DOI: $10.9790 / 0837-2307106270 \quad$ www.iosrjournals.org $\quad 68 \mid$ Page
}


Religion and Constructivism. Constructivism has become an increasingly prominent theoretical approach to International Relations since its emergence in the 1980s. Its main focus is on the role of ideational factors and the social construction of world politics. ${ }^{49}$ Constructivists argue that the world is constituted socially through inter-subjective interaction and that ideational factor such as norms, identity and ideas which are generally central to the constitution and dynamics of world politics. ${ }^{50}$ Nicholas Onuf's 'World of Our Making' and Alexander Wendt's 'Anarchy is What States Make of it' are two pioneering pieces of work for the development of constructivism in International Relations. Constructivism argues that Ideational factors matter and all the ideas are socially constructed and therefore ideas can change over time. The role of religion in international politics is significant because of its emphasis on ideas, norms, identity, and culture. Role of religion in thinking about international culture is important. Wendt distinguishes three cultures of anarchy: the Hobbesian war of all against all; Lockean self-interested competition restrained by the recognition of sovereign units' right to exist; and Kantian friendship expressed as the expectation of mutual non-violence. It is easy to imagine how different expressions of religion could have an elective affinity with these different cultures of anarchy. Hobbesian enmity coincides with Manichaean religion; Lockean restrained competition coincides with religion-based rules of restraint in warfare; and Kantian friendship based in religious (or secular) tenets of common identity or altruism. Religion plays a critical role in constructing human culture and way of life. ${ }^{51}$

\section{CONCLUSION}

Religion is inextricably linked to the international system, and this is something of a mixed blessing. Religion seems to problematize international relations lately, but historically it has contributed greatly to the development of international system. Friedrich Kratochwil pointed importance of religion in contemporary world affairs and claimed, 'The intersection of religion and international relations has become a major focus for the analysis of contemporary international relations' ${ }^{52}$ Again, Jonathan Fox urged to bring back the study of religion for better understanding current affairs and asserted, "no understanding of international relations can be complete without bringing religion into the discipline'. ${ }^{53}$ Also, Samuel Huntington uplifted religious study to the center of international politics and wrote in his "Clash of civilizations" thesis that religion has become so central that it should supplant existing paradigms and become the main prism for thinking about international politics. ${ }^{54}$

Moreover, as Hans Kueng pointed that wars begin in the minds of men and it is in the minds of men that the defenses of peace must be constructed. ${ }^{55}$ Religion plays a significant role in constructing peace in the minds of human beings and accordingly has important influence in constructing future international affairs. With the resurgence of religion and increased influence of religions in world affairs, the future international system is likely to be influenced more by religious beliefs than ever before. The world leaders need to understand these developments and possibilities and take future policies accordingly. If peaceful dimensions of the religions can be availed and truly put into action, the future international relations can be peaceful and prosperous.

\section{BIBLIOGRAPHY}

[1]. Ahmad, Rafi., "The Islamic Khilafat - Its Rise, Fall, and Re-emergence", Available at http://www.alislam.org/egazette/updates/the-islamic-khilafat-its-rise-fall-and-re-emergence/

[2]. Alam, Aksadul., Islamisation in Bengal: A Review of Theories, A Paper Presented at an International Conference, New Delhi, January 27, 2005.

[3]. Coulombis, Theodore. and James Wolfe, Introduction to International Relations: Power and Justice (Prentice-Hall: Englewood Cliffs, N.J, 1978).

[4]. Donnelly, Jack., "Realism", Theories of International Relations eds. by Scott Burchill, Andrew Link later, Richard Davetak, (New York: Palgrave Macmillan, 2005).

[5]. Elliott, Lorraine, Mark Beeson, Shahram Akbarzadeh, Greg Fealy and Stuart Harris, "Religion, Faith and global politics", Published by Department of International Relations (RSPAS), The Australian National University, July 2006.

\footnotetext{
${ }^{49}$ Paul D. Williams, “Constructivism”, In Security Studies: An Introduction, (New York: Rutledge, 2008), p.59.

${ }^{50}$ Ibid, p.60.

${ }^{51}$ Jack Snyder, Op.cit., p.16.

${ }^{52}$ Friedrich Kratochwil, Op.cit., p. 113.

${ }^{53}$ Jonathan Fox, Op.cit.

${ }^{54}$ Op.cit., p.18.

55 Jerry Filteau, "Hans urges peaceful revolution against roman absolutism", Available at

http://ncronline.org/news/faith-parish/hans-kung-urges-peaceful-revolution-against-roman-absolutism, Accessed on December 9, 2011.

DOI: $10.9790 / 0837-2307106270 \quad$ www.iosrjournals.org $\quad 69 \mid$ Page
}


[6]. Fox and Sandler, "Bringing Religion into International Relations", Available at http://books.google.com.bd/books/about/Bringing_religion_into_international_rel.html?id=6g85Csl6Yhs C\&redir_esc=y, Accessed on November 25, 2011.

[7]. Filteau, Jerry., "Hans urges peaceful revolution against roman absolutism", Available at http://ncronline.org/news/faith-parish/hans-kung-urges-peaceful-revolution-against-roman-absolutism, Accessed on December 9, 2011.

[8]. Frettinghum, Edmund., "Security and Construction of Religion in International Politics", Department of International Politics, Aberystwyth University, 2009.

[9]. Gözaydın, İştar., "Religion as Soft Power in the International Relations of Turkey", Available at http://www.google.com/url?sa=t\&rct=j\&q=religion\%20as\%20soft \%20power\%20in\%20the\%20internatio nal $\% 20$ relations $\% 20$ of $\% 20$ turkey $\% 20 \&$ source=web\&cd=1\&ved=0CB0QFjAA\&url=http $\% 3 \mathrm{~A} \% 2 \mathrm{~F} \% 2 \mathrm{~F}$ www.psa.ac.uk\%2Fjournals\%2Fpdf\%2F5\%2F2010\%2F1365_1228.pdf\&ei=A3PpTtu2F421hAeaYTZCg\&usg=AFQjCNEkIUFwOiPPROjzHmAEEaQyYQ5x5g\&cad=rja

[10]. Hansen, Eric O., Religion and Politics in The International System Today (Cambridge: Cambridge University Press, 2006).

[11]. Held, David., "The Development of Modern State" in Stuart Hall and Bram Gieben, eds. Formations of Modernity (Cambridge: Polity press, 1995).

[12]. Hurd, Elizabeth Shakman., "The Politics of Secularism in International Relations", (Princeton: Princeton University Press, 2008).

[13]. Ikenberry, G. John., "Religion and International Relations Theory", September/October 2011, Available athttp://www.foreignaffairs.com/articles/68139/religion-and-international-relations-theory-religionculture-and\#

[14]. Goldstein, Joshua S., International Relations (Singapore: Pearson Education, 2004), fifth Edition.

[15]. Jackson, Robert and George Sorenson., Introduction to International Relations: Theories and Approaches (Oxford: Oxford University Press, 2003).

[16]. Kratochwil, Friedrich., "Religion and (Inter-) National Politics: On the Heuristics of Identities, Structures, and Agents", Alternatives vol. 30 (2005), p. 113.

[17]. Mingst, Karen., "The Historical Context of Contemporary International Relations", Essentials of International Relations (New York: Norton, 1998).

[18]. Pals, Daniel L., Seven Theories of Religion, Oxford University Press, 1996.

[19]. "Religion and Modern State", Available at http://www.whyreligion.com/titles/r63.htm

[20]. Snyder, Jack., Religion and International Relations Theory, (New York: Columbia university press:2011). Available

http://books.google.com.bd/books?id=O51O6_cMgAQC\&printsec=frontcover\&source=gbs_ge_summary _r\&cad $=0 \# \mathrm{v}=$ onepage \&q\&f=false

[21]. Williams, Paul D., "Constructivism”, in Security Studies: An Introduction, (New York: Rutledge, 2008).

[22]. The Holy Al Quran

[23]. The Holy Bible 